\title{
PENINGKATAN HASIL BELAJAR MATEMATIKA MELALUI PEMBELAJARAN KOOPERATIF TIPE MAKE A MATCH
}

\author{
Paimin \\ SMP Negeri 3 Bendosari, Sukoharjo \\ Email: maspay65@gmail.com
}

\begin{abstract}
Abstrak
Penelitian ini bertujuan untuk meningkatkan hasil belajar matematika melalui model pembelajaran kooperatif tipe make a match pada siswa kelas IX SMP Negeri 3 Bendosari semester I tahun pelajaran 2018/ 2019. Penelitian ini adalah Penelitian Tindakan Kelas yang dilakukan di kelas IX SMP Negeri 3 Bendosari semester I tahun pelajaran 2018/ 2019 yang berjumah 24 siswa. Teknik pengumpulan data yang digunakan adalah tes, observasi, dan dokumentasi.Tahap-tahap analisis data dalam penelitian ini adalah pengumpulan data, reduksi data, penyajian data, dan penarikan kesimpulan. Indikator keberhasilan adalah nilai rata-rata tes siswa sekurang-kurangnya 70,0 dan banyak siswa dengan nilai di atas kriteria ketuntasan minimal (KKM) yaitu 65,0 mencapai $\geq 85 \%$. Berdasarkan penelitian yang telah dilakukan, dapat disimpulkan bahwa penerapan model pembelajaran kooperatif tipe make a match dapat meningkatkan hasil belajar matematika materi Kesebangunan siswa kelas IX SMP Negeri 3 Bendosari. Sebelum tindakan/prasiklus, hasil belajar siswa yang mencapai KKM 15 siswa atau 62,5 $\%$, pada siklus I, 19 siswa atau 78,1\% dan pada siklus II, 23 siswa atau 95,5\%. Nilai ratarata kelas sebelum tindakan/prasiklus sebesar 67,41 setelah tindakan siklus I sebesar 70,58 dan setelah tindakan siklus II sebesar 73,45.
\end{abstract}

Kata Kunci: Model pembelajaran kooperatif tipe make a match, hasil belajar matematika.

\begin{abstract}
This study aims to improve the learning outcomes of the matematics through learning model type make a match in students of IX SMP Negeri 3 Bendosari first semester academic year 2018/ 2019.This research is a Classroom Action Research conducted in class IX SMP Negeri 3 Bendosari first semester of academic year 2018/ 2019 with 24 students. Data collection techniques used are tests, observations, and documentation. The stages of data analysis in this study are data collection, data reduction, data presentation, and conclusion. The success indicator is the average score of the student's test at least 70.0 and many students with a value above the minimum mastery criteria (KKM) of 65,0 reach $\geq 85 \%$. Based on the research that has been done, it can be concluded that the application of cooperative learning model type make a match can improve learning result
\end{abstract}


of matematics letters student of IX SMP Negeri 3 Bendosari. Before the action / pre cycle, student learning outcomes reaching KKM 15 students or $62,5 \%$, in cycle I, 19 students or $78,1 \%$ and in cycle II, 23 students or $95,5 \%$. The average value of the class before the action / pre cycle was 67,41 after the first cycle action was 70,8 and after the second cycle action was 73,45 .

Keywords: Cooperative learning model type make a match, learning outcomes of mathematics.

\section{PENDAHULUAN}

Banyak siswa yang sulit dalam memahami penjelasan yang disampaikan oleh guru matematika, membuat siswa acuh dan bahkan tidak mau memperhatikan pelajaran. Pembelajaran matematika tidaklah sulit untuk dapat dipelajrai, dengan menggunakan model yang tepat akan membuat siswa mudah dalam memahami materi yang disampaikan oleh guru, siswa juga tidak mudah bosan, dan dengan adanya media pembelajaran juga turut membantu siswa dalam memahami materi yang disampaikan.

Berdasarkan hasil pengamatan penulis dengan teman sejawat di SMP Negeri 3 Bendosari, masalah yang dihadapi siswa adalah masih rendahnya hasil belajar matematika yang dimiliki oleh siswa. Hal ini disebabkan oleh siswa yang kurang aktif dalam pembelajaran berlangsung, siswa yang tidak mau berpirik dalam menyelesaikan soal, siswa yang kurang lancar dalam berbicara matematika, karena siswa kurang latihan mengerjakan soal. Rendahnya hasil belajar siswa dapat dilihat dari hasil nilai matematika yang kebanyakan masih di bawah standart ketuntasan belajar yaitu 65,00. Selain itu penulis juga mendapatkan informasi dari siswa di SMP Negeri 3 Bendosari, bahwa metode yang digunaka oleh guru yaitu ceramah, diskusi, dan penugasan juga membuat siswa bosan pada saat mengikuti pembelajaran. Ini membuat siswa menjadi pasif, ada juga takut pada saat mengikuti pembelajaran, dan membuat hasil belajar siswa menurun. Tidak tercapainya nilai KKM yang telah ditetapkan oleh sekolah yaitu 65,00. Di dalam kelas IX terdapat 24 siswa, sedangkan siswa yang tuntas didalam 1 kelas hanya ada sekitar 15 siswa, dan sebagian besar siswa masih banyak yang sulit dalam 
memahami menjelasan materi dari guru, dapat dikatakan siswa yang masih belum tuntas memiliki persentase $37,5 \%$, sedangkan siswa yang sudah tuntas ada $62,5 \%$.

Menurut Darsono (dalam Isjoni, 2011) aliran behavioristik, pembelajaran adalahusaha guru untuk membentuk tingkah laku yang diinginkan dengan menyediakan lingkungan atau stimulus, dan aliran kognitif mendefinisikan pembelajaran adalah sebagai cara guru memberikankesempatan kepada siswa untuk berpikir agar mengenal dan memahami sesuatu yang dipelajari.

Salah satu model pembelajaran yang dapat digunakan dalam proses pembelajaran adalah model pembelajaran kooperatif tipe make a match. Dimana model ini dikembangkan untuk mencapai hasil belajar yang berupa prestasi akademik, toleransi, memcapai keragaman dan perkembangan keterampilan sosial. Dengan model ini diharapkan siswa akan lebih aktif dalam bertanya dan dalam penyampaian pendapat, siswa juga diharapkan akan lebih dapat bersosialisasi dengan teman mereka dan dapat mengumpulkan banyak informasi tentang materi pembelajaran yang belum mereka ketahui sebelumnya. Selain itu, model pembelajaran kooperatif tipe Make a matchini juga memiliki kelebihan karena pembelajaran disusun dalam bentuk kelompok, dimana terdapat kelompok pembawa kartu pertanyaan, kelompok pembawa kartu jawaban, dan kelompok penilai. Sehingga model ini dianggap sebagai model yang dapat meningkatkan prestasi belajar matematika siswa. Namun perlu diadakan penelitian untuk dapat menyimpulkan bahwa model Make a match dapat meningkatkan prestasi belajar siswa terutama dalam pembelajaran matematika.

Menurut pendapat dari beberapa ahli tentang pembelajaran kooperatif tipe make a macth sebagai berikut: (1) Menurut Suprijono (2009 : 94) mengatakan pembelajaran kooperatif tipe make a match adalah pembelajaran yang menggunakan kartu-kartu; (2) Menurut Unodan Mohamad mangatakan pembelajaran kooperatif tipe make a match adalah pembelajaran yang menggunakan media berupa kartu pertanyaan dan kartu jawaban; (3) Pembelajaran kooperatif tipe make a match merupakan salah satu tipe pembelajaran kooperatif yang merupakan metode pembelajaran dengan 
membentuk kelompok-kelompok kecil yang juga bertujuan untuk berinteraksi antar siswa, yang mengajarkan kepada siswa bahwa untuk mencapai sesuatu tidak dapat dicapai secara sendiri, melainkan dikerjakan bersama-sama. Mengajarkan kepada siswa untuk dapat berinteraksi dan bergaul dengan siswa yang lain tanpa membedakan ras, suku, dan agama. Pembelajaran kooperatif tipe make a match ini membagi siswa menjadi beberapa kelompok yaitu kelompok pembawa kartu pertanyaan,kelompok pembawa kartu jawaban, dan sebagai kelompok penilai.

Siswa diajarkan untuk belajar bersama dengan siswa yang lain, saling bertukar informasi yang mereka miliki, dan mengajarkan sportifitas dalam kegiatan kelompok terebut. Pembelajaran kooperatif tipe make a match ini adalah variasi dalam kegiatan kelompok yang sebelumnya pernah ada, dengan penggunaan metode ini diharapkan siswa dapat lebih aktif didalam menerima pembelajaran dan diharapkan siswa tidak bosan dan lebih mudah dalam menerima penjelasan yang diterangkan oleh guru yang membuat peningkatan prestasi belajar siswa terutama pada pembelajaran matematika.

Langkah-langkah kegiatannya adalah sebagai berikut : (1) Guru membagi siswa dibagi dalam beberapa kelompok, setiap kelompok terdiri dari 4-6 siswa yang masing-masing dalam kelompok memiliki peran yaitu kelompok pembawa kartu pertanyaan, dan kelompok pembawa jawaban; (2) Guru menyiapkan beberapa kartu yang berisi beberapa konsep atau topik yang cocok untuk sesi review, satu untuk bagian kartu soal dan bagian lainnya kartu jawaban.Setiap siswa mendapat satu kartu; (3) Setiap siswa memikirkan jawaban atau soal kartu yang dipegang; (4) Kemudian setiap siswa mencari pasangan yang mempunyai kartu yang cocok dengan kartu yang mereka bawa; (5) Setiap siswa yang telah mendapatkan pasangan kartunya yang cocok sebelum waktu yang ditentukan habis akan diberikan tambahan poin oleh guru; (6) Setelah satu babak kemudian kartu dikocok lagi agar tiap siswa mendapat kartu yang berbeda dari kartu sebelumnya, demikian seterusnya.Kemudian diakhir kegiatan guru bersama-sama dengan siswa menyimpulkan dari materi yang telah dipelajari.

Alternatif yang dapat ditempuh dalam meningkatkan hasil belajar siswa adalah melalui kreatifitas guru dalam memilih model pembelajaran.Pemilihan 
model pembelajaran yang tepat dan bervariasi dapat meningkatkan hasil belajar siswa terutama dalam mata pelajaran matematika. Karena tidak semua model cocok digunakan dalam penyampaian materi, kreativitas guru sangatlah diperlukan dalam pemilihan model pembelajaran yang akan digunakan. Dengan menggunakan model pembelajaran yang tepat dan bervariasi dalam penyampaian materi dapat membantu siswa untuk meningkatkan ide, gagasan dan kreativitas yang dimiliki siswa. Peran guru sebagai fasilitator sangatlah membantu siswa mengembangkan kreativitas yang mereka miliki, siswa juga akan dituntut untuk aktif dalam proses pembelajaran, ini membuat siswa menjadi lebih bersemangat dan bertanggung jawab dalam menemukan hasil jawaban yang diberikan kepada siswa. Pembentukan kelompok juga sangat berguna dalam meningkatkan hasil belajar siswa terutama pada mata pelajaran matematika, siswa juga akan belajar untuk bersosialisasi dengan teman yang lain, dengan demikian akan menjalin kekompakan dan kerja sama dalam menemukan solusi dari masalah yang diberikan kepada siswa. Pembentukan kelompok akan membuat siswa menjadi senang dalam mengikuti pembelajaran dan tujuan yang didasarkan pada alasan bahwa untuk mencapai sesuatu tidak dapat dicapai secara sendiri, melainkan harus dikerjakan secara bersama-sama, hal ini akan meningkatkan kekompakan, keaktifan, serta kerja sama. Siswa memungkinkan dapat meraih keberhasilan dalam belajar, di samping itu juga akan melatih siswa untuk meningkatkan keterampilan berpikir, dan keterampilan sosial seperti mengemukakan pendapat, menerima saran, bekerja sama dan rasa setia kawan.

Berdasarkan latar belakang di atas, maka dapat dirumuskan tujuan penelitian ini adalah: meningkatkan hasil belajar materi Kesebangunan pada siswa kelas IX SMP Negeri 3 Bendosari semester I tahun pelajaran 2018/ 2019 menerapkan model pembelajaran kooperatif tipe make a match dapat?"

\section{METODE PENELITIAN}

Penelitian ini adalah Penelitian Tindakan Kelas.Penelitian tindakan kelas merupakan suatu pencermatan terhadap kegiatan yang sengaja dimunculkan, dan 
terjadi dalam sebuah kelas (Arikunto, 2010).Penelitian ini dilaksanakan di SMP Negeri 3 Bendosari.Tahap-tahap pelaksanaan kegiatan dilakukan selama kurang lebih enam bulan yaitu sejak bulan Juli sampai dengan Desember 2018. Peneliti sebagai guru SMP Negeri 3 Bendosari bertindak sebagai subjek yang melakukan tindakan kelas. Teman sejawat sesama guru mata pelajaran matematika sebagai observer.Kepala Sekolah bertindak sebagai subjek yang membantu dalam perencanaan dan pengumpulan data. Subjek yang menerima tindakan adalah siswa kelas IX SMP Negeri 3 Bendosari semester I tahun pelajaran 2018/ 2019 sebanyak 24 siswa.Adapun langkah-langkah penelitian untuk setiap siklus pembelajaran adalah sebagai berikut:

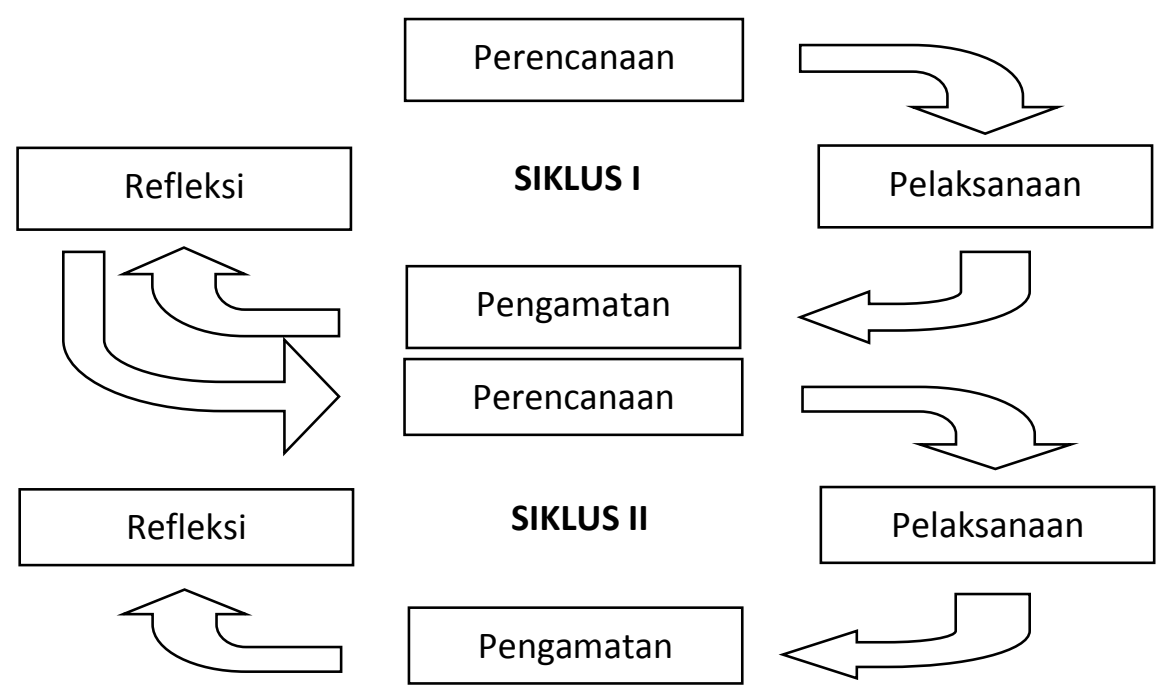

Gambar 1. Siklus Penelitian Tindakan (Arikunto, 2006)

Teknik pengumpulan data yang digunakan adalah: tes, observasi dan dokumentasi. Tes adalah serentetan pertanyaan atau latihan serta alat lain yang digunakan untuk mengukur keterampilan, pengetahuan inteligensi, kemampuan atau bakat yang dimiliki oleh individu dan kelompok (Arikunto, 2010). Tes digunakan adalah jenis tes hasil(achievement test) berupa kuis individu.Tes ini digunakan untuk mengukur pencapaian siswa setelah mempelajari materi. Hal ini dapat juga sebagai alat untuk mengetahui tingkat pemahaman siswa setelah mempelajari pokok bahasan membaca kalimat/paragraf dengan menggunakan model pembelajaran kooperatif tipe Make a match. Kuis individu yang dimaksudkan ini adalah tes tertulis. 
Tes tertulis adalah suatu teknik penilaian yang menuntut jawaban secara tertulis, baik berupa pilihan atau isian. Tes yang jawabannya berupa pilihan meliputi pilihan ganda, benar salah dan menjodohkan, sedangkan tes yang jawabannya berupa isian berbentuk isian singkat atau uraian (Suprijono, 2013).Observasi atau pengamatan dilakukan guna memperoleh data yang akurat, dengan menggunakan lembar observasi. Lembar observasi digunakan untuk memonitor dan mengevaluasi setiap tindakan agar kegiatan observasi tidak terlepas dari konteks permasalahan dan tujuan penelitian. Observasi yang digunakan adalah observasi sistematis, yaitu observasi yang dilakukan oleh pengamat dengan menggunakan pedoman sebagai instrumen pengamatan dan observasi non-sistematis yang dilakukan dengan tidak menggunakan instrumen pengamatan. Dokumentasi diperoleh dari hasil kuis siswa, lembar observasi, lembar wawancara, catatan lapangan, daftar siswa, dan foto-foto selama proses kegiatan belajar mengajar. Dokumentasi ini dimaksudkan adalah sebagai buktibukti konkret dari penelitian tindakan kelas tersebut.

Instrumen yang digunakan dalam penelitian berupa tes, lembar observasi dan lembar dokumentasi. Tes berbentuk tes tertulis maupun lisan yang dilakukan dalam post test dan kuis individu. Tes ini digunakan untuk mengetahui sejauh mana peningkatan hasil belajar Kesebangunan siswa dengan penerapan model pembelajaran kooperatif tipeMake a match. Lembar Observasi, digunakan lembar observasi hasil belajar siswa dan lembar observasi pelaksanaan pembelajaran kooperatif. Lembar observasi digunakan pada setiap pembelajaran sehingga kegiatan observasi tidak terlepas dari konteks permasalahan dan tujuan penelitian, untuk lembar hasil belajar siswa digunakan pada saat siswa dapat menyelesaikan permasalahan dengan kegiatan belajar mengajar dan sedangkan lembar observasi pelaksanaan kegiatan belajar mengajar dengan model pembelajaran Kooperatif TipeMake a match digunakan sebagai pedoman peneliti dalam melakukan observasi pelaksanaan kegiatan belajar mengajar dengan menggunakan model pembelajaran kooperatif tipeMake a match. Lembar dokumentasi ini bertujuan untuk mengetahui data siswa selama kegiatan penelitian berlangsung. Lembar dokumentasi ini berupa, foto-foto kegiatan pembelajaran, daftar hadir kegiatan 
pembelajaran, daftar hadir, daftar nilai, kartu pasangan soal/jawaban dan sebagainya.

Indikator keberhasilan kinerja dalam penelitian ini adalah meningkatnya hasil belajar matematika materi Kesebangunan siswa, yang ditunjukkan dengan meningkatnya nilai rata-rata tes siswa sekurang-kurangnya 70,0 dan banyak siswa dengan nilai di atas kriteria ketuntasan minimal (KKM) yaitu $\geq 65,0$ mencapai $\geq$ $85 \%$.

\section{HASIL PENELITIAN DAN PEMBAHASAN}

Deskripsi data hasil penelitian yang telah dilakukan di kelas IX SMP Negeri 3 Bendosari adalah sebagai berikut. Berdasarkan observasi awal di kelas IX mata pelajaran matematika dengan materi Kesebangunan diperoleh data, dari 24 siswa yang mencapai nilai kriteria ketuntasan minimal (KKM) sebanyak 15 siswa (62,5\%), dengan nilai rata-rata kelas sebesar 67,41. Penelitian ini dilakukan dengan indikator kinerja nilai rata-rata tes siswa sekurang-kurangnya 70,0 dan banyak siswa dengan nilai di atas kriteria ketuntasan minimal (KKM) yaitu $\geq 65,0$ mencapai $\geq 85 \%$.

Kemudian peneliti merencanakan observasi survai berikutnya untuk mengetahui kebenarannya.Pada kegiatan survei awal yang dilaksanakan pada hari Rabu, 16 Agustus 2018. Hasil observasi awal menunjukkan bahwa guruyang mendominasi kegiatan pembelajaran dan siswa cenderung tidak aktif.Salah satu solusi yang dikembangkan adalah penggunaan model pembelajaran yang baru yaitu dengan Model Pembelajaran Kooperatif Tipe Make a match (mencari pasangan). Dengan penggunaan model pembelajaran tersebut diharapkan akan menciptakan suasana belajar yang berbeda, bervariasi dan menyenangkan sehingga dapat menarikperhatian siswa, meningkatkan keaktifan siswa yang muara akhirnya meningkatkan hasil belajar siswa.

Tindakan kelas siklus I dilaksanakan pada rabu, 15 agustus 2018 di SMP Negeri 3 Bendosari kelas IX. Setelah langkah apersepsi dilanjutkan dengan penyampaian materi dengan model pembelajaran kooperatif tipe make a match. 
Berdasarkan hasil evaluasi pada siklus I menunjukkan adanya peningkatan hasil belajar siswa. Hasil belajar siswa sebanyak 19 mencapai nilai kriteria ketuntasan minimal (KKM) atau 78,1 \%, rata-rata kelas naik menjadi 70,58. Berdasarkan pengamatan tersebut dapat diketahui bahwa proses pembelajaran pada siklus pertama belum berhasilmaksimaldan belum mencapai indikator kinerja yang diharapkan. Peningkatan hasil, jika dibandingkan hasil prasiklus yang mencapai KKM sebanyak 15 siswa atau 62,5\% setelah diberi tindakan penerapan siklus I, siswa yang mencapai KKM sebanyak 19 siswa atau 78,1\%.

Tabel 1. Perkembangan Siswa yang Mencapai KKM Sebelum Tindakan/Prasiklus ke SiklusI

\begin{tabular}{lcc}
\hline Hasil Siswa & Prasiklus & Siklus I \\
\hline Siswa mencapai KKM & 15 & 19 \\
\hline
\end{tabular}

Dari tabel di atas dapat disimpulkan bahwa hasil belajar matematika materi Kesebangunan siswa dengan menerapkan model pembelajaran kooperatif tipe make a match, padapelaksanaan tindakan siklus I mengalami peningkatan. Siswa yang mencapai KKM Sebelum dilakukan tindakan atau prasiklus 15 siswa, setelah tindakan siklus I sebanyak 19 siswa sehingga meningkat 4 siswa.

Setelah dievaluasi bersama dari pelaksanaan tindakan pada siklus I yang digunakan sebagai bagian pertimbangan perencanaan pembelajaran siklus berikutnya, dengan perencanaan perbaikan untuk mengatasi kekurangan dan kesalahan yang dilakukan pada siklus I. Tindakan kelas siklus II dilaksanakan pada Rabu, 5 September 2018. Berdasarkan pembelajaran secara keseluruhan pada tindakan kelas siklus II menunjukan adanya peningkatan yang signifikan. Hasil belajar siswasebanyak 23 siswa $(95,8 \%)$ mencapai nilai kriteria ketuntasan minimal (KKM). Sehingga rata-rata nilai kelas IX naik menjadi 73,45.

Tabel 2. Perkembangan Siswa yang Mencapai KKM Siklus I ke Siklus II

\begin{tabular}{lcc}
\hline Hasil Siswa & Siklus I & Siklus II \\
\hline Siswa mencapai KKM & 15 & 23 \\
\hline
\end{tabular}


Dari tabel di atas dapat disimpulkan bahwa hasil belajar Kesebangunan siswa dengan menerapkan model pembelajaran kooperatif tipe make a match, padapelaksanaan tindakan siklus II mengalami peningkatan. Siswa yang mencapai KKM pada saat dilakukan tindakan siklus I sebanyak 15 siswa, setelah tidakan siklus II sebanyak 23 siswa sehingga meningkat 4 siswa.Berdasarkan hasil tersebut dapat diketahui bahwa proses pembelajaran sampai dengan pada siklus II berjalan dengan baik dan telah memenuhi indikator kinerja yang diharapkan.

Pada siklus I dan II dengan penerapan tindakan menggunakan model pembelajaran kooperatiftipe make a match, sehingga siswa lebih antusias dengan perasaan senang dalam mengikuti kegiatan pembelajaran. Nilai rata-rata siswa sejak sebelum diadakan penelitian hingga setelah diadakan penenelitian sampai dengan siklus II, dapat dilihat pada tabel berikut:

Tabel 3. Perkembangan Siswa yang Mencapai KKM Sebelum Tindakan/Prasiklus,Siklus I dan Siklus II

\begin{tabular}{lccc}
\hline Hasil Siswa & Prasiklus & Siklus I & Siklus II \\
\hline Siswa mencapai KKM & 15 & 19 & 23 \\
\hline
\end{tabular}

Dari tabel di atas dapat disimpulkan bahwa hasil belajar materi Kesebangunan siswa dengan menerapkan model pembelajaran kooperatif tipe make a match, di setiap pelaksanaan tindakan, baik siklus I dan siklus II mengalami peningkatan, yaitu: siswa yang mencapai KKM Sebelum dilakukan tindakan atau prasiklus 15 siswa, setelah tidakan siklus I sebanyak 19 siswa dan setelah tindakan siklus II sebanya 23 siswa, sehingga peningkatan kumulatif dari sebelum tindakan/prasiklus sampai dengan siklus II sebesar 8 siswa.

Tabel 4. Perkembangan Persentase Siswa Mencapai KKMSebelum Tindakan/Prasiklus, Siklus I dan Siklus II

\begin{tabular}{lccc}
\hline Hasil Siswa & Prasiklus & Siklus I & Siklus II \\
\hline Persentase Siswa Mencapai KKM & $62,5 \%$ & $78,1 \%$ & $95,8 \%$ \\
\hline
\end{tabular}


Dari tabel di atas dapat disimpulkan bahwa hasil belajar Fungsi siswa dengan menerapkan model pembelajaran kooperatif tipe make a match, di setiap pelaksanaan tindakan mengalami peningkatan, yaitu: persentase siswa yang mencapai KKM Sebelum dilakukan tindakan atau prasiklus 62,5\%, setelah tidakan siklus I sebanyak 78,1 \% dan setelah tindakan siklus II sebanya 95,8 \%.

Tabel 5. Perkembangan Nilai Rata-rata Kelas Sebelum Tindakan/Prasiklus, Siklus I dan Siklus II

\begin{tabular}{llll}
\hline & Prasiklus & Siklus I & Siklus II \\
\hline Nilai rata-rata & 67,41 & 70,58 & 73,45 \\
\hline
\end{tabular}

Dari tabel di atas dapat disimpulkan bahwa hasil belajar materi Kesebangunan siswa dengan menerapkan model pembelajaran kooperatif tipe make a match, di setiap pelaksanaan tindakan mengalami peningkatan, yaitu: nilai rata-rata kelas sebelum dilakukan tindakan atau prasiklus adalah 67,41, setelah tidakan siklus I adalah 70,58 dan setelah tindakan siklus II adalah 73,45 sehingga dari kondisi awal sebelum tindakan/prasiklus sampai dengan tidakan pada siklus II terjadi peningkatan sebesar 6,04.Dari uraian di atas dapat disimpulkan bahwa model pembelajaran kooperatif tipe make a matchdapat meningkatkan hasil belajarmateri Kesebangunan siswa kelas IX SMP Negeri 3 Bendosari semester I tahun pelajaran 2018/ 2019.

\section{SIMPULAN}

Berdasarkan hasil penelitian dapat disimpulkan, dengan penerapan model pembelajaran kooperatif tipe make a match dapat meningkatkan hasil belajar materi Kesebangunan siswa kelas IX SMP Negeri 3 Bendosari semester I tahun pelajaran 2018/ 2019.

Penelitian Tindakan Kelas (PTK) yang dilaksanakan di SMP Negeri 3 Bendosari ini sudah berjalan dengan cukup baik dan hasil yang baik pula. Namun masih banyak hal yang perlu diperbaiki. Oleh karena itu, peneliti memberikan beberapa saran. (1) Siswa diharapkan dapat lebih meningkatkan kemampuan diri 
melalui peran aktifnya dalam mengikuti kegiatan belajar mengajar. Peran aktif tersebut meliputi peran aktif dalam bertanya, mengemukakan pendapat maupun mempresentasikan gagasannya. (2) Guru matematika hendaknya dapat menumbuh kembangkan kreativitas dalam menjalankan profesinya sebagai fasilitator dan motivator dalam menyampaikan pembelajaran secara kreaktif dan inovatif pada siswa dalam penyampaian materi, sehingga siswa dapat menerima dan memahami materi yang diajarkan dengan baik. (3) Penelitian Tindakan Kelas (PTK) ini diharapkan akan membawa dampak positif terhadap perkembangan sekolah yang nampak pada peningkatan prestasi belajar siswa sehingga dapat meningkatkan prestasi dan kualitas sekolah.

\section{DAFTAR PUSTAKA}

Arikunto, S. 2006. Prosedur Penelitian Suatu Pendekatan Praktik. Jakarta: Rineka Cipta.

Hamalik, Oemar. 2004. Proses Belajar Mengajar. Jakarta: Bumi Aksara.

Isjoni. 2007. Cooperative Learning Efektifitas Pembelajaran Kelompok. Bandung: Alfabeta.

Sudjana, N. 1989. Cara Siswa Aktif dalam Proses Belajar Mengajar. Bandung : Lembaga Penelitian KIP Bandung.

Depdiknas. 2014. Buku Guru Matematika. Jakarta : Pusat Kurikulum dan Perbukuan, Balitbang, Kemdikbud.

Dimyati dan Mudjiono. 2013. Belajar dan Pembelajaran. Jakarta : PT Rineka Cipta.

Mulyasa. 2012. PraktikPenelitian Tindakan Kelas. Bandung : PT Remaja Rosdakarya.

Rudi Salam, Zunaira Zunaira, Risma Niswaty. 2012. Meningkatkan Hasil Belajar Membuat Dokumen Melalui Penggunaan Model Pembelajaran Kooperatif Tipe Make a match (Mencari Pasangan).Jurnal Office Vol 2, No 2 (Juli-Sept 2012).

Suprijono, Agus. 2009. Cooperative Learning Teori dan Aplikasi Paikem. Yogyakarta: Pustaka Pelajar. 